\title{
ANALYSIS OF DOMESTIC VIOLENCE ON WOMEN'S HEALTH
}

\author{
Susan de Alencar Silva ${ }^{1}$, Kerle Dayana Tavares de Lucena ${ }^{2}$, Layza de Souza Chaves Deininger ${ }^{3}$ \\ Hemílio Fernandes Campos Coelho ${ }^{4}$, Rodrigo Pinheiro de Toledo Vianna5, \\ Ulisses Umbelino dos Anjos 6
}

\begin{abstract}
Introduction: Violence against women is characterized by damage to physical and mental health of the victim, and is not linked solely to the use of physical force, but also the idea of submission, culturally ingrained in gender relations, in which man behaves itself as being dominant and women an inferior being. As result of violence, women are hindered in their social life, repressed and psychologically shaken. It is a public health problem of great magnitude in the world. It is known that women are more vulnerable to health problems and has unique needs, differentiated from other groups in society, such as prevention, control and combat to physical and mental illnesses. According to the National Policy for Integral Attention to Women's Health, these injuries are more linked with gender issues such as the situation of discrimination in society than to biological factors. Gender inequalities, historically produced and legitimated by culture and society, put women in inferiority and depreciation position. In this context, violence is used as a mechanism of maintenance and confirmation of male power over women. Objective: Investigating the health problems resulting from domestic violence against women. Methods: An exploratory study with a qualitative approach, in the city of João Pessoa, involving 406 women who met the inclusion criteria. The speeches made by the interviewees were coded as analysis technique of speech. Results: The main diseases cited were headache, nausea, feeling of insecurity, stress, depression, difficulty with new relationships. Conclusion: The grievances caused from domestic violence in women who suffer permeate the physical damage, interfere with quality of life and surpass. It is important to give visibility to the phenomenon and insert gender concepts in the training of health professionals, providing tools for them to meet in a humane way and emancipatory approach to this population segment.
\end{abstract}

Key words: women's health, gender identity, domestic violence.

\section{INTRODUCTION}

Violence against women is characterized by damage to physical and mental health of the victim, and it is not linked solely to the use of physical force, but also to the idea of submission, culturally ingrained in gender relations, in which man behaves as the dominant and women an inferior being. As a result of violence, women are hindered in their social life, repressed and psychologically shaken. It is a public health problem of great magnitude in the world. The World Health Organization (WHO) conducted a study which revealed that the overall prevalence of physical and / or sexual violence by intimate partner was of $30,0 \%{ }^{1}$.
In Brazil the phenomenon is expressed in a violent death rate of 26,2 per 100.000 inhabitants for the year 2010. According to the Map of Violence 2012 , in an analysis the rate of homicidal violence, referring to data from the same year is of 4,4 per 100.000 inhabitants in women, published by the Sangari Institute ${ }^{2}$.

In João Pessoa there is not an organization of data about domestic violence, which makes difficult to the researchers doing their research work, as well as directing the data to the authorities so that they can make decisions in order to prevent and/or minimize the effects of violence in question. In addition, it realizes that the data submitted by Public Security Departments of the State of Paraiba

1 Graduate Student of Nursing at the Faculty of Medical Sciences of Paraiba. João Pessoa (PB), Brazil.

3 Nurse, Master's Student, Federal University of Paraíba (UFPB), Professor at the Faculty of Medical Sciences of Paraiba. João Pessoa (PB), Brazil.

4 Statistician, Doctorate from the Federal University of Pernambuco, Professor at the Federal University of Paraiba. João Pessoa (PB), Brazil.

5 Nutritionist, Doctor of Public Health, Federal University of Paraiba. João Pessoa (PB). Brazil.

6 Electrical Engineer, Professor, Federal University of Paraiba/UFPB. João Pessoa (PB), Brazil.

Corresponding author: Kerle Dayana Tavares de Lucena. E-mail: kerledayana@yahoo.com.br

Suggested citation: Silva SA, Lucena KDT, Deininger LSC, Coelho HFC, Vianna RPT, Dos Anjos UU. Analysis of domestic violence on women's health. Journal of Human Growth and Development. 25(2): 182-186. DOI: http://dx.doi.org/10.7322/ jhgd.103009

Manuscript submitted: Oct 22 2014, accepted for publication Dec 192014 
and João Pessoa Municipal Health Department on the subject in question, do not match the reality so far, which reinforces the relevance of this study ${ }^{3}$.

The State of Paraiba created nine Women's Police Stations, shelters, Women's Reference Centre as well as providing training courses prioritizing the routine of health professionals in improving it to deal with the reality of victimized women and thus, qualify professionals to cope the phenomenon ${ }^{4}$.

It is known that women are more vulnerable to health problems and has unique needs, differentiated from other groups in society, such as prevention, control and combat the physical and mental illnesses. According to the National Policy for Integral Attention to Women's Health, these injuries are more linked with gender issues, such as the situation of discrimination in society than to biological factors ${ }^{5}$.

Thus, it is necessary to deepen studies about the impact of violence on women's lives generated from gender inequality. It is believed that this study may be used in the planning and implementation of public and educational policies with actions that can minimize the damage caused by violence due to the naturalization of the phenomenon.

In this context, the study is justified by the timely need to recognize complications caused by domestic violence against women and talk about care the tools that can give visibility to such injuries and strengthen the debate concerning empower women for emancipation gender. It aimed to analyze the health problems resulting from domestic violence against women.

\section{METHODS}

This is a field research, exploratory, descriptive, of a qualitative approach. The research place was the city of João Pessoa, involving a universe of 406 women who met the inclusion criteria. They are: women over 18 who agreed to participate in the survey and who were at home at the time of collection, excluding thus women under the age of 18, who were not present for the collection and who refused participating in the research.

Data were collected in September 2014, through an interview with open questions that identified the understanding of women in relation to violence against women, the types of violence that know, if they suffered any type of violence and if they noticed any injury to health after the episodes of aggression.

The first stage consisted in transcribing the interviews and, at the second time, there were made identifications of subjects and/or figures in the speeches of the interviewees on the elaborate issues. Then the texts were made and organized in blocks of meanings by coincidence/divergence theme. The interviews were identified by the letter " $E$ " followed by numbers from one to fifteen ( $E 1$, $E 2, E 3 \ldots E 15)$, corresponding to the number of women interviewed, in order to maintain the confidentiality and anonymity of participants.
The empirical material produced by the interviews were coded and treated by a technique in which it is understood that the text is an organized whole of sense, and in a certain universe of meaning. The meaning of the text is given both for its internal structure, which are the grammar rules, as the historical context of the moment in which it was produced. Therefore, the text is a fully linguistic object and completely historical ${ }^{6}$.

Analyzing the speech is related to understanding the stories that the human being produces, realizing its values, that is, the meaning that it assigns its reality in each historical moment. This study was conducted according to ethical principles in research and their Resolution no 466/ 12 of the National Health Council7. The research project was approved by the Research Ethics Committee (CAAE: 20418813.0.0000.5183).

In the process of analysis and discussion, we tried to dock the empirical material produced to the relevant literature. Speeches identified in interviews enabled the creation of the following subcategory: The health consequences of domestic violence suffered by victims.

\section{RESULTS}

According to the empirical material produced from the testimony of the women, it was found that $60 \%$ of women reported not having suffered any kind of violence and $40 \%$ said they had suffered. With regard to types of violence, $67 \%$ reported experiencing violence of psychological type and 33\% of physical and psychological kind.

With regard to knowledge of the research subjects about the types of violence, they have cited the physical and psychological types, not mentioning other forms of violence against women. When asked about the health problems after the act of violence, the answers were correlated to aspects of insecurity, stress, depression, and difficulties with new relationships and even sleep and rest harmed. Some women attributed the violence suffered to the effects of physical symptoms, such as: headache, discomfort in the cervical spine, frequent nausea, dizziness and hypertensive peaks.

Given the above, emerges the need to deepen the understanding of violence against women and about equal rights for men and women who historically have been more effective in the discursive level and even on the intent of the law. However, this in itself has not been able to overlap traditions, prejudices and interests of a male majority occupying key points of power.

The physically manifested violence, psychological pressure, heavy workloads, nonrecognition of the rights to their life, their body and will, are different manifestations of violence that compromises the quality of life of women around the world. 


\section{DISCUSSION}

\section{The health consequences of domestic violence suffered by victimized women:}

According to the speeches made by the women of this research, it can be seen in the reports the effects of violence suffered by them, according to E11: "I spent many sleepless nights during this phase, was afraid to leave the house, felt nauseous and cry very often..." (E12) and "I realized that I became a more stressed person, I also realized that I have more difficulty in relating with people."(E11).

Worsening is defined as any injury to physical, mental and social health of people caused by harmful situations, such as accidents, poisoning, drug abuse, and self-inflicted injuries or by third parties $^{8}$.

Apart from these situations that may trigger worsening; a study published in 2009 found that violence against women leads to effects such as depression, anxiety, recurrent urinary infections, chronic pelvic pain, post-traumatic stress disorder, irritable bowel syndrome, among other signs and symptoms ${ }^{9}$.

It is known that violence is about fights, insults, shoving, humiliation and shame and although physical marks were in fact a finding of violence, they betray negative effects on the mental health of women, especially the humiliation, suffering and shame that affect their self-esteem ${ }^{10}$. However, violence inflicted against women results in significant losses in their physical, sexual, psychological, social and occupational health, and it is necessary their referral to specialized health services in addressing these issues, aiming the improvement in their quality of life ${ }^{11}$. Consequences clearly perceived when observing the statements of the subjects in the following interviews: "...nervous breakdowns, depression, back pain, headaches." E3; "... Stress, high blood pressure, loss of appetite and impaired spiritually." E6.

It is noteworthy that there is a process of "psychologizing" when it comes to diseases that do not leave physical marks, ie only the physical marks perceived are easily treated, as the consequences understood as psychological, are generally disregarded, mainly by health professionals at the time that the women search ${ }^{12}$.

It is hoped that, instead of professional women who are dissatisfied with "no disease" or "do not care", it can identify and offer routes to the problem being minimized, ie, there must be counseling by professional so that women feel comfortable to share their doubts, desires, expectations, fears and uncertainties; this professional's role is to listen to the woman, understand her problem, do not judge her, map support networks, risks in which the woman is exposed, look for alternatives to solve the problem and respect the opinion of the woman ${ }^{5}$. However, even before this process there is still a woman's difficulty in admitting she is subjected to violence, by fear, shame or guilt ${ }^{13-14}$.
Health services and its professionals have the role to identify, control and prevent violence against women, providing support for rehabilitation of the same, as these services are the first places sought by women attacked ${ }^{15-16}$. Thus, it is for professionals and health managers to review their roles before the treatment and prevention of violence, in order to promote a comprehensive care and quality to users. But what we see is that, despite the serious impact of violence on women's health, there is certain unpreparedness of professionals to dealing with situations of gender violence in the health system ${ }^{17}$. This unpreparedness is also related to cultural and moral values that professionals have in relation to the theme, which ends up reflecting on their service to the victim ${ }^{16}$.

Therefore, the identification as well as the care for the woman suffering violence is highly complex, the existence of various factors that prevent them, most of them related to lack of communication, lack of understanding of violence and especially fear of reprisals by the perpetrator, among other factors.

\section{CONCLUSION}

Violence against women is present in various social and cultural spheres ${ }^{18}$, reassuring the complexity of the phenomenon. The study analyzed the complications caused from domestic violence against women that go beyond physical symptoms.

Women who suffer domestic violence presented disorders and psychological consequences. Other variables can be added, such as reduced quality of life and impaired sense of satisfaction with life, the body, and sex life and interpersonal relationships. There are other studies reporting that there is a significant association between sexual violence and high rates of PTSD, with symptoms that include dissociation, freezing and hypervigilance and can remain for a long time ${ }^{19}$.

It should be noted that the fact that women in many situations shut up and allow violence should be to the fact that it is under the domain of a symbolic violence maintained by the patriarchal culture that is fed by the social order and allowed by the State. Not only does society view violence against women in a naturalized way, influencing through its institutions such as the family and the Church, or through socialization held in schools, maintaining this framework, but also the state that does not meet the demands of women in a sufficient way for lacking their policies for efficient management, and concepts that go beyond the gender issue, however, although not the only variable, is closely linked to social inequalities in the country ${ }^{20}$.

It needs to broaden the debate about violence against women within the health services so that professionals can understand the phenomenon and instrumentalize to deal with the consequences of the violence suffered, promoting the visibility of injuries and dialogue on gender emancipation and women's empowerment. 


\section{REFERENCES}

1. Garcia LP, Freitas LRS, Höfelmann DA. Avaliação do impacto da Lei Maria da Penha sobre a mortalidade de mulheres por agressões no Brasil, 2001-2011. Epidemiol Serv Saúde. Brasília: 22(3): 383-94. DOI: http://dx.doi.org/ 10.5123/S1679-49742013000300003

2. Waiselfisz JJ. Mapa da violência 2012: os novos padrões da violência homicida no Brasil. Instituto Sangari; São Paulo: 2011; p.60-65.

3. Lucena KDT, Silva ATMC, Morais RM, Silva CC, Bezerra IMP. Análise espacial da violência doméstica contra a mulher entre os anos de 2002 e 2005 em João Pessoa, Paraíba, Brasil. Cad Saúde Pública. 2012; 28(6): 1111-21. DOI: http://dx.doi.org/10.1590/ S0102-311X2012000600010

4. Dias ARC, Machado C. Gênero e violência conjugal - Uma relação cultural. Aná Psicológica. 2008; 26(4): 34-5.

5. Brasil. Ministério da Saúde. Política Nacional de Atenção Integral à Saúde da Mulher: Princípios e diretrizes. Ministério da Saúde; Brasília: 2004.

6. Fiorin JL. Introdução ao pensamento de Bakhtin. São Paulo: Ática; 2006; p.144.

7. Brasil. Ministério da Saúde. Resolução n0466/ 12 do Conselho Nacional de Saúde. Diretrizes e normas regulamentadoras para pesquisas envolvendo seres humanos. Diário Oficial da União 13 jun 2013; Seção 1.

8. Brasil. Ministério da Saúde. Portaria nº 104 de 25 de janeiro de 2014. Define as terminologias adotadas em legislação nacional, conforme o disposto no Regulamento Sanitário Internacional 2005 (RSI 2005), a relação de doenças, agravos e eventos em saúde pública de notificação compulsória em todo o território nacional e estabelece fluxo, critérios, responsabilidades e atribuições aos profissionais e serviços de saúde. Diário Oficial da União 26 jan 2011; Seção 1.

9. D'Oliveira AFPL, Schraiber LB, Hanada H, Durand J. Atenção integral à saúde de mulheres em situação de violência de gênero - uma alternativa para a atenção primária em saúde. Ciênc Saúde Coletiva. 2009; 14(4):1037-1050. DOI: http://dx.doi.org/10.1590/S141381232009000400011

10. Monteiro CFS, Souza EO. Vivência da violência conjugal: fatos do cotidiano. Texto Contexto Enferm. 2007; 16(1): 26-31.

DOI: http://dx.doi.org/10.1590/S0104-07072 007000100003
11. Leôncio KL, Baldo PL, João VM, Biffi RG. O perfil de mulheres vitimizadas e seus agressores. Rev Enferm UERJ. 2008; 16(3):307-12.

12. Almeida LR, Silva ATMC, Machado LS. O objeto, a finalidade e os instrumentos do processo de trabalho em saúde na atenção à violência de gênero em um serviço de atenção básica. Interface. Botucatu: 2014; 18(48):47-60. DOI: http: / /dx.doi.org/10.1590/1807 57622014.0560

13. Schraiber LB, D'Oliveira AFPL. Romper com a violência contra a mulher: como lidar desde a perspectiva do campo da saúde. Athenea Digital. 2008; 14: 229-36.

14. Rocha SV, de Almeida MM, Araújo TM. Violência contra a mulher entre residentes de áreas urbanas de Feira de Santana, Bahia. Trends Psychiatry Psychother. 2011; 33(3): 164-8. DOI: http://dx.doi.org/10.1590/S223760892011000300006

15. Blake MT, Drezett J, Machi GS, Pereira VX, Raimundo RD, Oliveira FR, et al. Factors associated to late-term abortion after rape: literature review. Reprod Clim. 2014; 29(2): 60-5. DOI: http://dx.doi.org/10.1016/ j.recli.2014.08.003

16. Oliveira EM, Barbosa RM, Moura AAVM, von Kossel K, Morelli K, Botelho LFF, et al. Atendimento as mulheres vítimas de violência sexual: um estudo qualitativo. Rev Saúde Pública. 2005; 39(3):376-82. DOI: http:// dx.doi.org/10.1590/S0034-89102005000 300007

17. Brasil. Ministério da Saúde. Atenção integral para mulheres e adolescentes em situação de violência doméstica e sexual: matriz pedagógica para formação de redes. Brasília: 2011.

18. Signorelli MC, Auad D, Pereira PPG. Violência doméstica contra mulheres e a atuação profissional na atenção primária à saúde: um estudo etnográfico em Matinhos, Paraná, Brasil. Cad Saúde Pública. Rio de Janeiro: 2013; 29(6):1230-40. DOI: http://dx.doi.org/ 10.1590/S0102-311X2013000600019

19. Oliveira APG, Cavalcanti VRS. Violência doméstica na perspectiva de gênero e políticas públicas. Rev Bras Crescimento Desenvolv Hum. 2007; 17(1): 39-51.

20. Souza FBC, Drezett J, Meirelles AC, Ramos DG. Aspectos psicológicos de mulheres que sofrem violência sexual. Reprod Clim. 2012; 27(3): 98-103. DOI: http://dx.doi.org/10.1016/ j.recli.2013.03.002 


\section{RESUMO}

Introdução: A violência contra a mulher caracteriza-se por danos à saúde física e mental da vítima, e não está ligada apenas ao uso da força física, mas também à ideia de submissão, culturalmente impregnada nas relações de gêneros, na qual o homem comporta-se como ser dominante e a mulher um ser inferior. Como consequência da violência, as mulheres ficam prejudicadas em sua vida social, reprimidas e psicologicamente abaladas. Trata-se de um problema de Saúde Pública de grande magnitude no mundo. Sabe-se que a mulher é mais vulnerável a problemas de saúde e apresenta necessidades singulares, diferenciada dos demais grupos da sociedade, tais como: prevenção, controle e combate às enfermidades físicas e psíquicas. Segundo a Política Nacional de Atenção Integral à Saúde da Mulher, estes agravos estão mais ligados com as questões de gênero, como a situação de discriminação na sociedade, do que aos fatores biológicos. As desigualdades de gênero, produzidas historicamente e legitimadas pela cultura e sociedade, colocam mulheres em posição de inferioridade e desvalorização. Nesse contexto, a violência é utilizada como mecanismo de manutenção e confirmação do poder masculino sobre a mulher. Objetivo: Investigar os agravos à saúde, resultantes da violência domestica contra as mulheres. Método: Estudo exploratório com abordagem qualitativa, no município de João Pessoa, envolvendo 406 mulheres que atenderam aos critérios de inclusão. Os discursos obtidos pelas entrevistadas foram codificados conforme técnica de analise do discurso. Resultados: Os principais agravos citados foram cefaleia, náuseas, sentimento de insegurança, stress, depressão, dificuldade com novos relacionamentos. Conclusão: Os agravos causados a partir da violência doméstica nas mulheres que a sofrem perpassam os danos físicos, interferem na qualidade de vida delas e as oprimem. É importante dar visibilidade ao fenômeno e inserir conceitos de gênero na qualificação dos profissionais de saúde, instrumentalizando-os para atender de forma humanizada e com enfoque emancipatório a esse segmento populacional.

Palavras-chave: saúde da mulher, identidade de gênero, violência doméstica. 